\title{
Investigating the Relationship Between Schools and Families of Children with Chronic Diseases in the East of Turkey
}

\section{Gamze Yilmaz ${ }^{1 *}$ and Sevinç Polat ${ }^{2}$}

${ }^{1}$ Ağrı İbrahim Çeçen University School of Health, Department of Pediatric Nursing, Ağrı, Turkey

${ }^{2}$ Assistant Professor, Bozok University School of Health, Department of Pediatric Nursing, Yozgat, Turkey

\begin{abstract}
Objective: The purpose of this study is to investigate the relationship between schools and families of children with chronic diseases.

Design: The study conducted was designed as a descriptive and relational study.

Methods: The population of the study comprised of the teachers and parents of primary school children attending 28 primary schools in Central Ağrı, who also have a chronic disease. Two thirds (2/3) of these schools was selected using a simple random sampling method. The study was conducted with 98 parents and 100 teachers that accepted to participate in the study. Descriptive information of the parents and teachers, and two different subject-related questionnaires were used to gather data between 15 March and 30 April 2008 for this study. Data were evaluated by using percentages and chi-squares.
\end{abstract}

Results: Results of study concluded that $83.9 \%$ of mothers and $73.8 \%$ of fathers shared their child's disease with their teachers; $43.6 \%$ of mothers and $63.9 \%$ of fathers had never met their child's teacher prior to her/his illness; and $76.9 \%$ of mothers and $61.1 \%$ of fathers met with their child's teacher from parents' meeting to parents' meeting after their child became ill. In terms of illness and adaptation to school, half the mothers and $54.8 \%$ of fathers collaborated with their child's teacher; $61.9 \%$ of mothers and $66.7 \%$ of fathers collaborated with their child's teacher regarding diet, medication, and activity.

Conclusions: Results of study concluded that the parent-school relationship of children with chronic diseases was inadequate. It is recommended that parent-teacher and healthcare personnel collaboration is improved so that children with chronic diseases can continue their school life in the same way as their peers, they can cope with the difficulties they experience due to their disease, and succeed academically.

Keywords: Child; Chronic Disease; Parent-School Relationship

\section{Introduction}

Today, the number of children and adults with chronic diseases is constantly increasing; chronic diseases are one of the major health issues seen throughout the world, and in all industrialized countries [1]. It is a known fact that $1 \%-2 \%$ of the entire child population has a chronic health issue that affects daily activity or requires daily treatment [2].

Subject-related studies in literature report that children with chronic diseases experience various difficulties in adapting to school and social life [3]. Teachers have one of the most important roles in helping children adapt to schools. More often than not, teachers cannot receive adequate information from the parents and healthcare personnel regarding the overall health state of the child. Parents avoid informing teachers of their child's illness because they cannot foresee the reaction of teachers towards their child's illness, they are worried their child's illness will become common knowledge, or that their child will be treated differently $[1,4,5]$. After taking into consideration the different situations, teachers should establish solid communications with the ill child and their family, lean towards activities that make staying at school for the child easy, and decrease their anxiety, and should have realistic expectations regarding the child in order for ill children to take part in school activities like normal children; however, they should not be over protective [6-10].

One of the health objectives, set by the World Health Organization, for everyone in the European Region for the $21^{\text {st }}$ century was, "Adolescents should be healthier by the year 2020 and should be able to play their part in society in a healthy manner." This objective highlights the importance of school health services [11, 12]. The school health services throughout Turkey, in particular in the East of the country, are not at the required level. The parent-school collaboration is extremely important in terms of school efficacy, and the social, emotional, academic development, and academic success of the student [13]. Bilgin [14] reported that teachers conducted successful studies in order to develop parent-school relations. Literature states that parents only come to school when requested to do so for parents' meetings, and that the collaboration between family and school, the two most important elements that play a first degree role in preparing children for life, is insufficient $[15,16]$. In his study, Aslan [17] identified that there was no regular communication between schools and family in Turkey, and that relationships were unplanned and random.

The purpose of this study is to investigate the relationship between schools and families of children with chronic diseases.

\section{Methods}

\section{Design}

The study conducted was designed as a descriptive and relational study.

*Corresponding author: Gamze Yilmaz, Ağrı İbrahim Çeçen University Schoo of Health 04100- Ağrı, Turkey, Tel: 04722154000; Fax: 04722150720; E-mail: gamzeyilmaz@live.com

Received November 10, 2011; Accepted December 16, 2011; Published December 18, 2011

Citation: Yilmaz G, Polat S (2011) Investigating the Relationship Between Schools and Families of Children with Chronic Diseases in the East of Turkey. J Nurs Care 1:103. doi:10.4172/2167-1168.1000103

Copyright: ( 2011 Yilmaz G, et al. This is an open-access article distributed under the terms of the Creative Commons Attribution License, which permits unrestricted use, distribution, and reproduction in any medium, provided the original author and source are credited. 


\section{Study Population}

The population of the study comprised of the teachers and parents of primary school children attending 28 primary schools in Central Ağrl, who also have a chronic disease. Two thirds (19) of these schools were selected using a simple random sampling method; the parents and teachers of 107 primary school students having a chronic disease and attending these schools were planned to be included in the study. However, the study was conducted with 98 parents and 100 teachers as 9 of the parents, and 7 of the teachers refused to participate in the study.

\section{Data collection}

Two different questionnaires, one directed at parents and the other for teachers were used to gather data for this study. The questionnaires were prepared by researchers based on related examples in literature.

The parent questionnaire: A questionnaire comprised of questions that investigate the socio-demographic characteristics of parents and ill children, whether or not parents share their child's illness with their teacher, the frequencies of their visits before the child become ill and after they inform the teacher of their child's illness, and how much they collaborate with teachers in terms of illness and school adaptation, medication, diet, and activity.

The teacher questionnaire: A questionnaire comprised of questions about the descriptive properties of teachers, the level of knowledge they have regarding the child's illness, whether or not they talk about the child's illness, whether or not they make a special effort to get in contact with the parents, whether or not they help the ill child to catch up in their lessons and homework, the teachers' thoughts on how helpful they are in supporting the children to continue their education successfully and whether or not their level of support is adequate, and the level of information they gain during training regarding ill children and their school life.

\section{Completing Questionnaires}

Headmasters of the relevant schools were visited to determine the teachers with chronically ill children in their class in order to complete the teacher questionnaire. Teachers were provided information regarding the study, and appointments were made according to their availability. The questionnaire was given to teachers that accepted to participate in the study. Researchers went back to the school the following day in order to collect the completed questionnaire. The contact numbers of parents with chronically ill children were obtained from the schools in order to complete the parent questionnaire. Parents were contacted and provided information regarding the study over the phone; those that accepted to participate in the study were asked to complete the questionnaire sent to them via their children. Researchers went back to the school the following day in order to collect the completed questionnaires.

Chronic diseases were defined as illnesses, disorders, and disabilities present three months, or more, before the interview, or since birth, in accordance with literature [18]. The chronic diseases of children were categorized in seven groups based on systems; respiratory system diseases (Group 1), neurological diseases (Group 2), cardiovascular system-related diseases (Group 3), urinary system diseases (Group 4), endocrine system diseases (Group 5), hematologic-oncologic diseases (Group 6), and musculoskeletal system diseases (Group 7).

$49.0 \%$ of children participating in the study were classified under Group 1, 15.3\% were classified under Group 2, 12.2\% were classified under Group 3, and 8.2\% were classified under Group 6, while those classified under Group 4, Group 5, and Group 7 were 5.1\%.

\section{Statistical analysis}

A Statistical Package for the Social Sciences (SPSS) software, Version 11.5 for Windows, was used to conduct statistical analysis. Percentage distributions and the Chi Square Significance Test were used to assess data. P-values less than 0.05 were regarded as statistically significant.

\section{Ethical Considerations}

Verbal and written approvals were obtained from the related organizations before initiating the study. An ethical approval was obtained from the Research Ethics Committee at Atatürk University. The parents and teachers were informed about the purpose of the research, and assured of their right to refuse to participate or to withdraw from the study at any stage. The parents and teachers were informed that participation in the study was voluntary.

\section{Results}

$69.6 \%$ of mothers included in the study were aged between 26 and $35,63.5 \%$ were primary school graduates, and $94.6 \%$ were unemployed. $42.8 \%$ of fathers participating in the study were aged 46 and over, $52.4 \%$ were primary school graduates, and all of them were employed. $57 \%$ of participating families were nuclear families, $54 \%$ had four or more children, and 55\% had outgoings exceeding their income. $56.1 \%$ of the chronically ill children were boys, $41.8 \%$ were aged between 9 and $11,38.8 \%$ had been suffering from their illness between 1 and 4 years, and $38.8 \%$ had been suffering from their illness between 5 and 8 years (Table 1). $56 \%$ of teachers participating in the study were aged

\begin{tabular}{|c|c|c|c|c|}
\hline \multirow[b]{2}{*}{ Characteristics } & \multicolumn{2}{|c|}{ Mothers $(n=56)$} & \multicolumn{2}{|c|}{ Fathers $(n=42)$} \\
\hline & Number & $\%$ & Number & $\%$ \\
\hline $\begin{array}{l}\text { Age } \\
26-35 \\
36-45 \\
46 \text { and over }\end{array}$ & 39 & $\begin{array}{l}21.4^{69.6} \\
8.9\end{array}$ & $\begin{array}{ll} & 12 \\
12 & \\
18 & \end{array}$ & $\begin{array}{ll} & 28.6 \\
28.6 & \\
42.8 & \end{array}$ \\
\hline $\begin{array}{l}\text { Education Level } \\
\text { Not Primary school graduate } \\
\text { Primary level } \\
\text { High school }\end{array}$ & $\begin{array}{l}35 \\
12\end{array}$ & $\begin{array}{l}16.1 \\
63.5 \\
21.4\end{array}$ & $\begin{array}{l}9 \\
22 \\
11\end{array}$ & $\begin{array}{l}21.4 \\
52.4 \\
26.2\end{array}$ \\
\hline $\begin{array}{l}\text { Alive } \\
\text { Yes } \\
\text { No }\end{array}$ & 55 & $\begin{array}{l}98.2 \\
1.8\end{array}$ & $\begin{array}{l}41 \\
1\end{array}$ & $\begin{array}{l}97.6 \\
2.4\end{array}$ \\
\hline $\begin{array}{l}\text { Employment Status } \\
\text { Employed } \\
\text { Unemployed }\end{array}$ & $\begin{array}{l}3 \\
53\end{array}$ & $\begin{array}{l}5.4 \\
94.6\end{array}$ & $\begin{array}{l}42 \\
---\end{array}$ & $\begin{array}{l}100.0 \\
--\end{array}$ \\
\hline Total & 56 & 100.0 & 42 & 100.0 \\
\hline Characteristics of children & \multicolumn{2}{|l|}{ Number } & \multicolumn{2}{|r|}{$\%$} \\
\hline $\begin{array}{l}\text { Gender } \\
\text { Girl } \\
\text { Boy } \\
\text { Age } \\
6-8 \\
9-11 \\
12-14 \\
\text { School Year } \\
\text { Level } 1 \\
\text { Level } 2 \\
\text { IIIness Period } \\
\text { Less than a year } \\
\text { 1-4 years } \\
5-8 \text { years } \\
9 \text { years and over }\end{array}$ & $\begin{array}{l}43 \\
55 \\
\\
27 \\
41 \\
30 \\
\\
76 \\
22 \\
4 \\
38 \\
38 \\
18\end{array}$ & & $\begin{array}{l}43.9 \\
56.1 \\
\\
27.6 \\
41.8 \\
30.6 \\
\\
77.6 \\
22.4 \\
4.0 \\
38.8 \\
38.8 \\
18.4\end{array}$ & \\
\hline Total & 100 & & 100.0 & \\
\hline
\end{tabular}

Table 1: Socio-Demographic Characteristics of Parents and Children. 
between 20 and 29, 56\% were female, $78 \%$ were class teachers, and $48 \%$ had five, or less, years of experience (Table 2). $83.9 \%$ of mothers and $73.8 \%$ of fathers share their child's illness with their teacher. $43.6 \%$ of mothers and $63.9 \%$ of fathers never met their child's teacher prior to his/her illness. $76.9 \%$ of mothers and $61.1 \%$ of fathers only met up with their child's teacher at parents' meetings after their child's illness. In terms of illness and adaptation to school, half the mothers and $45.2 \%$ of fathers collaborated with their child's teacher; $61.9 \%$ of mothers and $66.7 \%$ of fathers did not collaborate with their child's teacher regarding diet, medication, and activity (Table 3 ). $31 \%$ of teachers had not spoken to the child about their illness; $48.4 \%$ of teachers expressed that they did not feel the need to talk to the child regarding their illness, and $35.5 \%$ thought that talking to the child about their illness would upset them. $54 \%$ of teachers made no special effort to communicate with parents of ill children. The branch of the teacher had an effect on the level of communication established with parents ( $p<0.05) .68 \%$ of teachers believed that they were helping ill children to catch up with their school work and homework; however, $66 \%$ of teachers believed that the support they offer ill children at school was insufficient. $79 \%$ of teachers expressed that they received no information about ill children and their school lives during their training sessions. The majority of teachers $(84 \%)$ believed that ill children would successfully continue with their education (Table 4).

\section{Discussion}

School children experience more difficulties when coping with chronic diseases [5]. It is important that teachers know about the child's illness in order for the child to receive the necessary support from family at home, and from teachers at school. More than half of the parents participating in this study expressed that their child's teacher was aware of their child's illness. In his study, Alçı [4] reported that $23.5 \%$ of parents had not informed teachers of their child's illness; however, nearly half of them $(43.3 \%)$ did not provide the teacher with the sufficient level of information regarding their child's illness. In their study, Coulter and Koester [19] discovered that parents had concerns about telling teachers about their child's illness. In his study, Andrews [20] identified that parents believed that the teacher should be notified of the child's disease; however, they preferred that the necessary information about the illness and treatment was provided by healthcare personnel.

\begin{tabular}{|l|l|l|}
\hline Descriptive Characteristics & Number & $\%$ \\
\hline Age & & \\
$20-29$ & 56 & 56.0 \\
$30-39$ & 37 & 37.0 \\
40 and over & 7 & 7.0 \\
\hline Gender & 56 & 56.0 \\
Female & 44 & 44.0 \\
Male & & \\
\hline Department & 78 & 78.0 \\
Class Teacher & 22 & 22.0 \\
Branch Teacher & & \\
\hline Years of Experience & 48 & 48.0 \\
5 years and below & 35 & 35.0 \\
6-10 years & 17 & 17.0 \\
11 years and over & & \\
\hline Class Taught & 78 & 78.0 \\
Level 1 (first five years) & 22 & 22.0 \\
\hline Level 2 & & 22.0 \\
\hline Class Size & 22 & 48.0 \\
20- 29 & 48 & 30.0 \\
\hline $30-39$ & 30 & \\
40 and over & & \\
\hline Total & & 100 \\
\hline
\end{tabular}

Table 2: Socio-Demographic Characteristics of Teachers $(\mathrm{N}=100)$.
$43.6 \%$ of mothers and $63.9 \%$ of fathers never met their child's teacher prior to his/her illness. $76.9 \%$ of mothers and $61.1 \%$ of fathers met with their child's teacher only at parents' meetings after their child's illness. The overall meeting frequency of parents and teachers for this study was insufficient. Literature also states similar findings to those of our study; parents only attend parents' meeting [15]. In his study, Demirbulak [21] identified that mothers had better communication with school in comparison to fathers, and that the level of communication deteriorated together with the increase in education level of parents. Leitch, Lauri \& Sandra, and Tangri [22] determined that the level of communication with the school decreased together with the decrease in the education level of parents.

In terms of illness and adaptation to school, half the mothers and $45.2 \%$ of fathers collaborated with their child's teacher. Numerous subject-related studies in literature report that ill children cannot adapt to school and social life and they experience various difficulties [3]. Even though the attitude and behaviour of teachers is extremely important in ill children adapting to school, parents included in the study failed to establish the desired level of collaboration with teachers.

More than half of the parents participating in this study collaborated with teachers regarding the subject medication, diet, and activity. Literature states that a set of medication children need to take during school hours should be put in their school bags, and a spare set should be kept in a cupboard at school under the supervision of the teacher in order to make sure that there are no disruptions in the treatment of children with chronic diseases. Literature also states that family, teachers, and school management should work together in order to keep the child away from factors that may trigger their illness such as cigarette smoke, excessive effort, eating foods that disrupt their dietary needs, and excessive stress [23]. Parents participating in this study were identified to have no collaboration with their child's teacher in an effort to support the school life of their ill child.

Literature talks about the benefits of allowing ill children, regardless of their age group, to express their problems and need for help, to ask questions, and to talk about the causes and results of their illness [24]. It is a satisfactory finding that $69 \%$ of teachers participating in this study talked to ill children about their illness and shared their worries; however, near to half of the teachers expressed that they did not talk to ill children about their illness because they did not feel the need to do so, which proves the teachers lack of knowledge on the subject.

$54 \%$ of the teacher participating in this study made no special effort to get in touch with the parents of ill children. The branch of the teacher had an effect on the level of communication established with parents $(p<0.05)$. This result only proves that branch teacher must increase the level of sensitivity of other teachers towards ill children. Literature states that teachers place great importance on teacher-parent interaction, in particular [15]. In his study, Bilgin [14] reported that teachers carried out successful studies to improve teacher-parent relationships.

More than half the teachers participating in this study help ill children to catch up on their schoolwork and homework. Literature states that teachers need to help ill children to catch up on their schoolwork and homework in order for them to be successful in school $[25,26] .66 \%$ of teachers participating in this study expressed that they felt the support they were providing ill children was inadequate. This result proves that teachers do not have the adequate knowledge to provide ill children with the professional support, as well as illustrating that factors such as the excessive number of children in a class, and the physical conditions of the schools also affect the support provided by teachers. 
Citation: Yilmaz G, Polat S (2011) Investigating the Relationship Between Schools and Families of Children with Chronic Diseases in the East of Turkey. J Nurs Care 1:103. doi:10.4172/2167-1168.1000103

Page 4 of 5

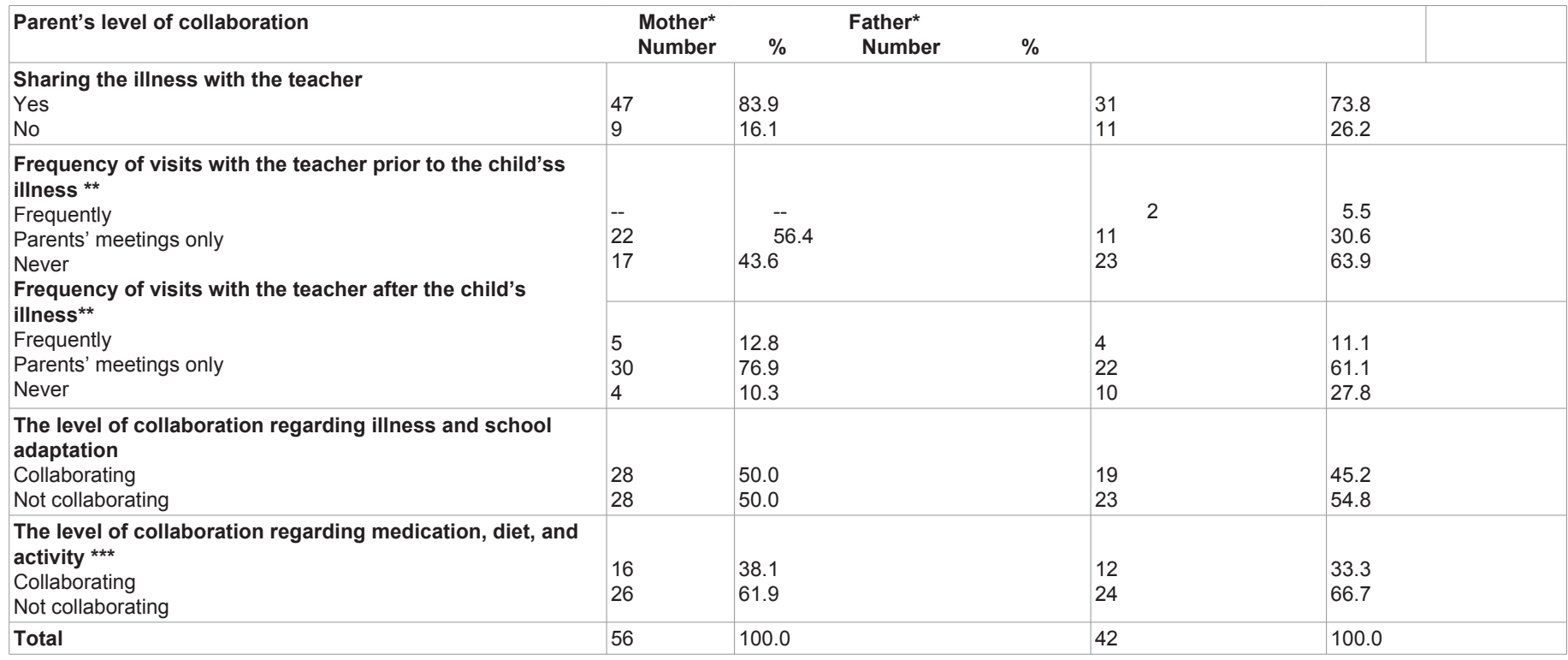

*Column percentage

**The number of mothers and fathers with children diagnosed ill after school started

${ }_{* * *}^{*}$ The number of mothers and fathers with children that take medication, and have diet and activity restrictions

Table 3: The Level of Collaboration Between Parents and Teachers Regarding The Child's Illness.

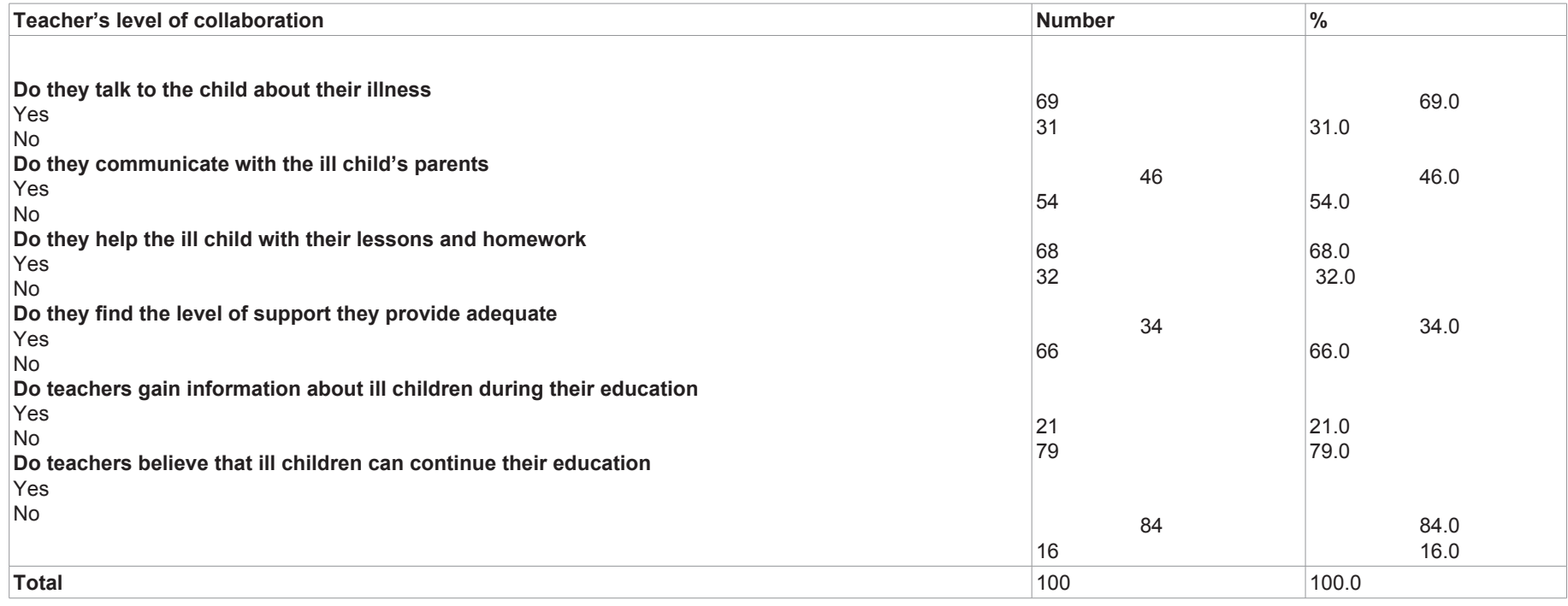

Table 4: The Level of Collaboration Between Parents and Teachers Regarding The Child's Illness

The majority of teachers participating in this study believed that ill children would successfully continue with their education. Johnson [27] reported that numerous teachers believed that health issues experience by children would restrict their education process

$79 \%$ of teachers participating in this study expressed that they were not informed about ill children and their school lives during their education. This result supports the assumption that teachers included in this study do not have adequate knowledge about ill children and their school lives. In their study, Gültekin and Baran [28] concluded that teachers need to attend regular in-house training courses in order to portray the correct approach towards ill children.

\section{Conclusion}

Results of this study conclude that meetings between parents and teachers are not healthy and functional. It was recommended that parents and teachers should be informed about chronically ill children, the collaboration better parents and teachers should be better established, and school health services should be activated in order to make sure that ill children can constantly continue with their school lives, and for them to have academic success and better life quality.

\section{References}

1. Çavuşoğlu H (2008) Pediatric Health Nursing. Illness and Children, $9^{\text {th }}$ Edition.

2. Gültekin G, Baran G, Illness and Children.

3. Dorenbaum D, Capelli M, Keene D, Mcgrath PJ (1985) Use of a child behaviour checklist in the psychosocial assessment of children with epilepsy. Clinical Pediatrics 24: 634-637.

4. Alçı E (1996) Difficulties Children with Epilepsy Face During their School Life CU Institute of Health Sciences, Postgraduate Thesis.

5. Children and adolescents with chronic diseases (2008). 
Citation: Yilmaz G, Polat S (2011) Investigating the Relationship Between Schools and Families of Children with Chronic Diseases in the East of Turkey. J 1 XUK\&DUH 1:103. doi:10.4172/2167-1168.1000103

Page 5 of 5

6. Spondyloarthropathy during childhood. Can the child go to school? (2008)

7. Elçigil A (2007) Can children with cancer go to school? CU High School of Nursing Journal 11: 40-46.

8. Bannon MJ, Wıldıg C, Jones PW (1992) Teachers' perceptions of epilepsy, Arch Dis Child 67:1467-1471

9. Tettenborn B, Kramer G (1991) Total patient care in epilepsy, Epilepsia 33: 28-32.

10. htpp://www.haberhavadis.com/NewDetails.aspx?NID=8539.

11. Aycan Ş, Afşar O, Demirören M, Evci D (2000) Health for everyone in the $21^{\text {st }}$ century. TR Ministry of Health, Basic Health Services General Directorate, Ankara.

12. Seçginli S, Erdoğan S, Demirezen E (2004) School health scanning programme: an example pilot study 13: 462-465.

13. Kolay Y (2008) The role and importance of school-parents-environment collaboration in the education.

14. Bilgin M (1990) The school-family collaboration and issues in secondary schools located in central districts of Ankara. An unpublished dissertation of the Institute of Social Sciences.

15. htpp://izmir3.meb.gov.tr/arge/etkin/3.html/

16. The precondition of success at school: Parent-teacher cooperation.

17. Aslan B (1984) Parent-teacher relationships at primary level education given at schools located in central districts of Ankara. Hacettepe University, Institute of Social Sciences, Unpublished dissertation

18. Şenol V, Sığmalı M, Çetinkaya F, Öztürk A (2011) Investigating the prevalence of chronic health issues in primary school students residing in central Kayseri, and the effective factors.

19. Coulter DL, Koester BS (1985) Information needs of parents of children with epilepsy. Developmental and Behavioural Pediatrics 6: 334-338.

20. Andrews SG (1991) Informing schools about children's chronic illnesses: parents'opinions. Pediatrics 88: 306-311.

21. Demirbulak D, Parent-Teacher Conferences Related to Trial. A study conducted on teacher-parent meetings.

22. Leitch L \& Sandra S (1988) Barriera to home-school collaboration, Educational Horizons 66: 70-74.

23. htpp://www.anneyizbiz/haber/haberdtl.php?hid=167.

24. Karabekiroğlu K (2008) The effect illness and hospitalisation has on children.

25. Avcı A (2007) Approaching children and adolescents with a chronic disease.

26. http://www.eğitimhane.com/forum/index.php?topic=5288

27. Johnson MP (1982) Support groups chronically. Pediatric Nursing 160-163.

28. Gültekin G, Baran G (2005) Assessing the focus of control in children aged between 9 and 14 with acute and chronic. Turkish Pediatric archive 40: 211-220 